\title{
Detecting total immunoglobulins in diverse animal species with a novel split enzymatic assay
}

\author{
Marija Drikic, Steven Olsen and Jeroen De Buck ${ }^{*}$ (])
}

\begin{abstract}
Background: Total immunolobulin G concentration is a useful, albeit underutilized, diagnostic parameter for health assessments of non-domestic animal species, due to a lack of functional diagnostic tools. Traditional assays, including enzyme-linked immunosorbent assay or radial immunodiffusion, require development of specific reagents (e.g., polyclonal antisera and appropriate protocols) for each animal species, precluding wide and easy adoption in wildlife welfare. As an alternative, bacterial virulence factors able to bind IgGs in antigen-independent manner can be used. To further simplify the diagnostic procedure and increase the number of species recognized by an assay, in this study a recently developed Split Trehalase immunoglobulin assay (STIGA) with bIBPs as a sensing elements was used to detect antibodies in 29 species from 9 orders. Three bacterial immunoglobulin binding proteins (protein G, protein A and protein L) were incorporated into STIGA reagents to increase the number of species recognized.

Results: IgG concentrations were detected through glucose production and produced signals were categorized in 4 categories, from not active to strong signal. Activation was detected in almost all tested animal species, apart from birds. Incorporation of Protein G, Protein A and Protein $L$ allowed detection of IgGs in 62, 15.5 and 6.9\% of species with a strong signal, respectively. Assays combining 2 bacterial immunoglobulin binding proteins as sensing element generally gave poorer performance than assays with the same bacterial immunoglobulin binding proteins fused to both trehalase fragments.
\end{abstract}

Conclusions: STIGA assays have potential to be further developed into an easily adoptable diagnostic test for total amount of IgGs in almost any serum sample, independent of species.

Keywords: Immunoglobulins, Bacterial immunoglobulin binding proteins, Trehalase, STIGA

\section{Background}

Determining total amount of immunoglobulin G (IgGs) in clinical samples can be valuable in diagnosing diseases like leukemia, establishing the immune status of an animal found dead or killed by hunters or evaluating passive transfer [1-3]. Still, this diagnostic parameter is not frequently used in evaluating animal health, due to limitations of current diagnostic tools. This is particularly true for wildlife species. Traditional diagnostic tests like ELISA or RID, used to estimate total IgG concentrations, rely on availability of polyclonal antisera or monoclonal

\footnotetext{
* Correspondence: jdebuck@ucalgary.ca

Department of Production Animal Health, Faculty of Veterinary Medicine, University of Calgary, Calgary, Alberta, Canada
}

antibodies specific for IgGs of targeted species. Furthermore, these tests often require customized protocols for each animal species, making them inadequate for wide adoption and easy adaptation to different species.

To overcome this limitation, indirect ELISAs were developed, with species-specific polyclonal antisera (secondary conjugate) replaced by proteins of bacterial origin able to bind IgGs (bacterial immunoglobulin binding proteins, bIBP) [4-6]. These proteins, considered virulence factors in bacteria, bind constant regions of IgGs (regions not involved in antigen recognition) and therefore are suitable for detection of all IgGs present in sample. Furthermore, they recognize IgGs from multiple animal species [7]. Due to this broad specificity, bIBP are used extensively in antibody purification.

(c) The Author(s). 2019 Open Access This article is distributed under the terms of the Creative Commons Attribution 4.0 International License (http://creativecommons.org/licenses/by/4.0/), which permits unrestricted use, distribution, and 
The most frequently used bIBP are protein A (pA), protein $\mathrm{G}(\mathrm{pG})$ and protein $\mathrm{L}(\mathrm{pL})$ [8]. They differ in species specificity and species affinity, in part due to different binding sites $[8,9]$. Protein A (pA), derived from Staphylococcus aureus, contains 5 Ig-binding domains which interact with an IgG region at the elbow interface between $\mathrm{CH} 2$ and $\mathrm{CH} 3$ domain [9-11]. Protein $\mathrm{A}$ has a strong affinity for all human IgG subclasses apart from IgG3. Also, it does not interact with IgG from many animal species (e.g. horse, cow or chicken) [12]. Protein G, isolated from streptococcal Lancefield groups $C$ and $G$, binds to the same $\operatorname{IgG}$ area as pA, but has only $3 \operatorname{IgG}$ binding domains $[13,14]$. Due to this difference in binding sites, when compared to $\mathrm{pA}$, pG interacts with all human IgG subclasses and with higher affinity [15]. Moreover, pG recognizes IgGs from a broader range of animal species [4]. Still, IgGs of several species recognized by $\mathrm{pA}$ are not recognized by $\mathrm{pG}$, making it impossible for $\mathrm{pG}$ to fully replace $\mathrm{pA}$. Protein L, from Peptostreptococcus magnus, binds to the light (L) chain of IgGs with 4 or 5 binding domains, specifically to the kappa chain, in an antigen-nonspecific manner $[16,17]$. Thus, its affinity towards IgG will be conditioned by the quantity of kappa chain present in the IgGs. Protein L has 2 independent IgG binding sites; each interacting with a different region on the light chain with a different affinity constant [18].

Different chimeric proteins containing binding sites from 2 bIBPs broaden the number of species recognized. Protein A/G has been used for purification purposes and in indirect ELISA. This chimeric protein is able to bind to IgGs coming from species recognized by $\mathrm{pA}$ and/or pG [19, 20]. Similar research has been done with chimeric proteins LG and LA [21-23], although their species specificity has not been fully investigated.

Recently, a novel detection assay (named Split TreA Immunoglobulin G Assay or STIGA) was developed to detect antibodies in bovine colostrum and calf serum [24]. The assay is based on split trehalase technology [25]. Briefly, trehalase (TreA), an E. coli enzyme that catalyzes the conversion of trehalose to glucose [26] was split in 2 non-functional fragments, $\operatorname{TreA}^{\mathrm{N}}(\mathrm{N})$ and $\operatorname{TreA}^{\mathrm{C}}(\mathrm{C})$. Each fragment was fused to protein $\mathrm{G}$ that acts as a sensor for immunoglobulins. The interaction between pG fused to TreA fragments and the constant region of the immunoglobulins induces dimerization of the 2 TreA fragments $\left(\operatorname{TreA}^{\mathrm{N}}\right.$ and $\operatorname{TreA}^{\mathrm{C}}$ ) and subsequent reconstitution and reactivation of the TreA. The newly activated TreA converts trehalose to produces glucose that is converted into a colorimetric signal by Glucose Oxidase coupled with Horse radish peroxidase. Split trehalase assay requires specific conditions (250 $\mathrm{mM}$ of trehalose, $\mathrm{pH}$ 6) for optimal performance as well as specific ratio between the split TreA and the analyte under investigation. Specifically, TreA dimerization efficacy decreases with the concentration of the analyte (IgG) [25]. In the previous study [24], split TreA carrying protein G (STIGA) was applied to quantify the amount of bovine IgGs in colostrum and calf serum. There, the optimal concentration of reagents for this type of assay was established and the new test format (92-well plate format) was developed. Furthermore, the performance of STIGA was compared with the gold standard (Radial Immunodifusion) and the correlation higher than 0.9 was observed demonstrating STIGA's suitability for quantification of IgGs.

The aim of this study was to modify the existing STIGA assay by incorporating different bIBPs (pG, pA and $\mathrm{pL}$ ) to act as sensing elements and to evaluate its ability to detect antibodies in a broad range of species.

\section{Results}

Detection of total lgG levels in various animal species

The STIGA version carrying protein G as sensor (GG assay) produced a strong signal with the majority of animal species tested. The GG assay detected IgGs with a strong signal in $62 \%$ of species analysed (18/29), but failed to detect IgGs in $20 \%(6 / 29)$ of species analyzed. The AA assay detected IgGs with a strong signal in 15\% (5 spp.) of species and medium to strong signal in $12 \%$ (3 spp.) of species. The AA assay detected with a weak signal IgGs in 45\% (14 spp.) of species. The LL assaydetected IgGs with a strong signal in only $6.9 \%$ (2 spp.) of species, whereas it displayed a weak signal for the majority of species (77.6\%; $22 \mathrm{spp}$.). Assays based on a combination of 2 sensor proteins detected fewer animal species with a strong signal compared to assays containing the same sensor protein. The AL assay failed to detect antibodies in 65\% (29 spp.) of species and it detected only $6.9 \%$ (2 spp.) of species with a strong signal. GA and GL assays yielded a strong signal in only 19\% (10 spp.) and 10.3\% (3 spp.) of species, respectively, whereas these 2 assays failed to detect IgGs in 57.9\% (11 spp.) and 50\% (14 spp.) of species, respectively (Table 1 ).

\section{Activation patterns in different animal orders and species} Various versions of STIGA had distinct activation patterns for various animal orders. Aves (Birds) IgGs were only weakly detected with LL assay. Other assays failed to detect antibodies for species in this order. Diprodontia (Marsupials) IgGs were detected weakly by AA, LL and AL assays. Artidactyla (Even-toed ungulates) and Perossidactyla (Odd-toed ungulates) IgGs were strongly detected by a GG assay, but weakly by AA or LL assays. Combination assays also performed weakly in these orders. Proboscidea (Proboscideans) IgGs were mainly detected with medium to strong signals with a GG assay. Carnivora (Carnivores) antibodies were mainly detected 
Table 1 Overall performance of 6 different STIGA assays in 29 different animal species. Percentage and number of species of which the IgG was detected by six different versions of STIGA assays at different intensities

\begin{tabular}{|c|c|c|c|c|c|c|}
\hline Signal Intensity & $\begin{array}{l}\text { AA assay } \\
\% \text { (spp.) }\end{array}$ & $\begin{array}{l}\text { LL assay } \\
\text { \%(spp.) }\end{array}$ & $\begin{array}{l}\text { GG assay } \\
\%(\text { spp.) }\end{array}$ & $\begin{array}{l}\text { AL assay } \\
\% \text { (spp.) }\end{array}$ & $\begin{array}{l}\text { GA assay } \\
\text { \%(spp.) }\end{array}$ & $\begin{array}{l}\text { GL assay } \\
\%(\text { spp.) }\end{array}$ \\
\hline Non Active & $19.0(5)$ & $6.9(2)$ & $20.7(6)$ & $65.5(19)$ & $37.9(11)$ & $50.0(14)$ \\
\hline Weak & $46.6(14)$ & $77.6(22)$ & $13.8(4)$ & $25.9(7)$ & $37.9(11)$ & $34.5(10)$ \\
\hline Weak to Medium & $6.9(2)$ & $8.6(3)$ & $0.0(0)$ & $1.7(1)$ & $3.4(1)$ & $3.4(1)$ \\
\hline Medium to strong & $12.1(3)$ & $0.0(0)$ & $3.4(1)$ & $0.0(0)$ & $1.7(1)$ & $1.7(1)$ \\
\hline Strong & $15.5(5)$ & $6.9(2)$ & $62.1(18)$ & $6.9(2)$ & $19.0(5)$ & $10.3(3)$ \\
\hline
\end{tabular}

In grey, the predominant performance of a specific STIGA version

with an AA assay, whereas GG and LL assays underperformed in detecting these antibodies. Lagomorpha (Lagomorphs) IgGs were detected by AA, GG and GA assays, whereas assays containing $\mathrm{L}$ protein as a sensor failed to detect antibodies in this order. Rodentia (Rodents) IgGs were detected with weak to medium signals by GG, GA and LG assays. Lastly, primate IgGs were efficiently detected with all 6 combinations of split TreA detection assay (Tables 2 and 3). Activation patterns specific to each species used in this study are shown in Table 3.

\section{Discussion}

The ability of bIBP to bind to IgGs in a speciesindependent manner has been used extensively for antibody purification and wildlife antibody ELISA [5, 6, 27]. In this study, bIBP were combined with a novel split TreA detection assay named STIGA to create a total
IgG detection assay easily applicable to samples from various animal species. A simple 1-step protocol was applied, without species specific optimization, to efficiently detect IgGs in 29 animal species. Six versions of the modified STIGA assay detected IgGs from almost all animal species examined, except birds and marsupials. Bird antibodies were only detected with an LL assay in a weak manner. This finding confirmed previous reports that bird IgGs (IgY) are not recognized by any bIBP due to their unique structure [12, 15]. Conversely, an inability to detect marsupial IgGs was unexpected, since their IgGs were bound at least by pA [5].

Various STIGA versions had varying detection efficiencies among animal orders, although their detection efficiency stayed constant within an order. Perhaps bIBP have evolved towards binding IgGs from different hosts, although our study design and number of species did not facilitate detailed analyses.

Table 2 Activation pattern of different versions of STIGA assay in 9 different animal orders

\begin{tabular}{|c|c|c|c|c|c|c|}
\hline Order & AA assay & LL assay & GG assay & AL assay & GA assay & LG assay \\
\hline Aves / Passeriformes* & 0.0 & 1.5 & 0.0 & 0.5 & 0.5 & 0.5 \\
\hline Diprodontia* & 1.0 & 1.0 & 0.0 & 0.0 & 0.0 & 1.0 \\
\hline Artidactyla & 0.8 & 1.0 & 4.0 & 0.3 & 0.9 & 0.3 \\
\hline Perissidactyla & 1.0 & 0.8 & 4.0 & 0.0 & 2.5 & 0.0 \\
\hline Proboscidea* & 1.0 & 1.0 & 3.0 & 0.0 & 1.0 & 0.0 \\
\hline Carnivora & 3.4 & 0.9 & 0.3 & 0.2 & 0.2 & 0.7 \\
\hline Lagomorpha* & 3.5 & 1.0 & 4.0 & 1.0 & 4.0 & 1.0 \\
\hline Rodentia & 0.8 & 1.3 & 2.0 & 0.7 & 2.0 & 2.5 \\
\hline Primates & 3.3 & 4.0 & 4.0 & 4.0 & 4.0 & 4.0 \\
\hline
\end{tabular}


Table 3 Activation pattern of different versions of STIGA assay in animal species from 9 different animal orders

\begin{tabular}{|c|c|c|c|c|c|c|c|c|}
\hline Order & & ecies & $\begin{array}{c}\mathbf{A A} \\
\text { assay }\end{array}$ & $\begin{array}{c}\text { LL } \\
\text { assay }\end{array}$ & $\begin{array}{l}\text { GG } \\
\text { assay }\end{array}$ & $\begin{array}{c}\mathrm{AL} \\
\text { assay }\end{array}$ & $\begin{array}{c}\text { GA } \\
\text { assay }\end{array}$ & $\begin{array}{c}\text { LG } \\
\text { assay }\end{array}$ \\
\hline Aves / Passeriformes & Starling & Sturnus vulgaris & 0.0 & 1.5 & 0.0 & 0.5 & 0.5 & 0.5 \\
\hline Diprodontia & Kangaroo & Macropus fuliginosus & 1.0 & 1.0 & 0.0 & 0.0 & 0.0 & 1.0 \\
\hline Artidactyla & White Tail Deer & $\begin{array}{l}\text { Odocoileus } \\
\text { virginianus }\end{array}$ & 1.0 & 1.0 & 4.0 & 0.0 & 1.0 & 0.0 \\
\hline & Elk & Cervus canadensis & 1.0 & 1.0 & 4.0 & 1.0 & 2.0 & 1.0 \\
\hline & Caribou & Rangifer tarandus & 0.5 & 1.0 & 4.0 & 0.5 & 0.5 & 0.0 \\
\hline & Dairy Cow & Bos taurus & 1.0 & 1.0 & 4.0 & 1.0 & 1.0 & 0.0 \\
\hline & Muskox & Ovibos moschatus & 0.5 & 1.0 & 4.0 & 0.5 & 0.5 & 1.5 \\
\hline & Wood Bison & $\begin{array}{l}\text { Bison bison } \\
\text { athabascae }\end{array}$ & 1.0 & 1.0 & 4.0 & 0.0 & 1.0 & 0.0 \\
\hline & Sheep & Ovis aries & 1.0 & 1.0 & 4.0 & 0.0 & 0.0 & 0.0 \\
\hline & Goat & $\begin{array}{c}\text { Capra aegagrus } \\
\text { hircus }\end{array}$ & 0.5 & 1.0 & 4.0 & 1.0 & 0.5 & 1.0 \\
\hline & Camel* & Camelus dromedarius & 1.0 & 0.5 & 4.0 & 0.0 & 3.5 & 0.0 \\
\hline & Addax & Addax nasomaculatus & 0.0 & 1.0 & 4.0 & 0.0 & 0.0 & 0.0 \\
\hline & Pronghorn Antelope & $\begin{array}{c}\text { Antilocapra } \\
\text { americana }\end{array}$ & 1.0 & 1.5 & 4.0 & 0.0 & 1.0 & 0.0 \\
\hline & $\begin{array}{l}\text { Turkmenian } \\
\text { Markhor }\end{array}$ & $\begin{array}{c}\text { Capra falconeri } \\
\text { heptneri }\end{array}$ & 0.5 & 1.0 & 4.0 & 0.0 & 0.0 & 0.0 \\
\hline Perissidactyla & Horse & Equus caballus & 1.0 & 1.0 & 4.0 & 0.0 & 1.0 & 0.0 \\
\hline & Zebra & $\begin{array}{l}\text { Equus zebra } \\
\text { hartmannae }\end{array}$ & 1.0 & 0.5 & 4.0 & 0.0 & 4.0 & 0.0 \\
\hline Proboscidea & Elephant & Elephas maximus & 1.0 & 1.0 & 3.0 & 0.0 & 1.0 & 0.0 \\
\hline Carnivora & Canine & $\begin{array}{l}\text { Canis lupus } \\
\text { familiaris }\end{array}$ & 4.0 & 1.0 & 0.5 & 0.0 & 1.0 & 1.0 \\
\hline & Feline & Felis catus & 3.5 & 1.0 & 1.0 & 0.5 & 0.0 & 1.0 \\
\hline & Bear & Ursus arctos & 3.0 & 0.5 & 0.0 & 0.0 & 0.0 & 0.0 \\
\hline & Siberian Tiger & $\begin{array}{c}\text { Panthera tigris } \\
\quad \text { altaica }\end{array}$ & 2.5 & 1.0 & 0.5 & 0.5 & 0.0 & 1.0 \\
\hline & Lion & Panthera leo & 3.5 & 1.0 & 0.0 & 0.0 & 0.0 & 1.0 \\
\hline & Cougar & Puma concolor & 4.0 & 1.0 & 0.0 & 0.0 & 0.0 & 0.0 \\
\hline Lagomorpha & Rabbit & $\begin{array}{l}\text { Oryctolagus } \\
\text { cuniculus }\end{array}$ & 3.5 & 1.0 & 4.0 & 1.0 & 4.0 & 1.0 \\
\hline Rodentia & Hamster & Mesocricetus auratus & 0.0 & 1.0 & 1.0 & 0.5 & 1.0 & 2.5 \\
\hline & Rat & Rattus norvegicus & 0.5 & 1.0 & 1.0 & 0.0 & 1.0 & 1.0 \\
\hline & $\begin{array}{c}\text { Vancouver Island } \\
\text { Marmot }\end{array}$ & $\begin{array}{c}\text { Marmota } \\
\text { vancouverensis }\end{array}$ & 2.0 & 2.0 & 4.0 & 1.5 & $4.0[4]$ & 4.0 \\
\hline Primates & Gorilla & $\begin{array}{l}\text { Gorilla gorilla } \\
\quad \text { gorilla }\end{array}$ & 4.0 & 4.0 & 4.0 & 4.0 & 4.0 & 4.0 \\
\hline & Japanese Macaque & Macaca fuscata & 2.5 & 4.0 & 4.0 & 4.0 & 4.0 & 4.0 \\
\hline
\end{tabular}


The ability of protein A and protein G to bind antibodies from various animal species was thoroughly investigated in previous studies [3-5]. In a study from 2002, pA and pG were used in a modified ELISA to detect antibodies from 160 zoo animal species representing 7 orders [5]. In general, our STIGA detection efficiency aligned with these findings. In the present study, Carnivore IgGs were detected mainly with an AA assay, whereas Even and Odd-toed ungulate IgGs were mainly detected with a GG assay. Primate IgGs were detected by both bIBP with equal efficiency. Exceptions were marsupial IgGs, which were weakly detected or not detected at all and proboscidean IgGs which were detected with a GG assay but not by an AA assay, contrary to previous findings [5]. Less is known about the ability of protein $\mathrm{L}$ to bind IgGs from various wildlife animal species. Regardless, at least 1 species per order was analyzed [17] which could be considered representative for the order, based on low variation within other orders. STIGA detection results confirmed previous studies regarding the ability of $\mathrm{pL}$ to bind IgGs. However, the LL assay was less efficient for detection of total IgGs, even though the $\mathrm{pL}$ affinity constant for IgGs is high. In that regard, pL is only able to detect the fraction of IgGs with a kappa light chain. Whereas in humans the kappa to lambda light chain ratio is $2: 1$, in cattle, for example, this ratio is $1: 20$. Consequently, the LL assay detected primate IgGs with a strong signal, whereas even-toed ungulate IgGs were detected weakly.

STIGA assays containing 2 distinct bIBP had surprisingly low efficiency in detecting IgG, with failure rates $\sim 50 \%$. Some exceptions were zebras and camels, where a GA assay had a strong signal, wherea the AA assay did not. Also, in VI marmot, whereas the AA and LL assays had weak signals, the AL assay had a strong signal. In previous studies, chimeric proteins carrying binding sites from 2 bIBP increased the number of species recognized [20], this was not the case when 2 distinct bIBP were used as sensing elements in STIGA. This was most likely failure of our STIGA assay to dimerize. It is probable that binding of 2 STIGA components to different sites on IgGs inhibited dimerization of the reporter components (TreA). This could be due to the improper length of the linkers or to steric hindrance.

Compared to techniques most frequently used for IgG detection, ELISA and RID, the method used in this study is faster, less laborious and does not require additional optimization. Furthermore, this method does not rely on antibody-specific polyclonal antisera essential for ELISA and RID. Reagents for this assay are produced in an inexpensive bacterial recombinant system, eliminating the need for animals in reagent production and reducing costs.
Some of the limitations of this study arose from opportunistic samples used. Details on immune status and age of animals were unknown. Both of these conditions have significant influences on overall quantity of IgGs in the sample and therefore on the outcome of STIGA detection. Too high concentration of IgGs impairs STIGA detection because then the two biosensor fragments are increasingly binding to different IgG molecules and unable to complement. This can be seen in Additional file 1: Figure S1. Too low concentrations result in trehalase activity below the threshold of detection. Furthermore, data on quality of sera was not available. Serum samples tested could have contained compounds (residues of previous treatment) with negative effects on the performance of split TreA assay.

\section{Conclusions}

In conclusion, STIGA assays has been successfully modified by incorporating three different bIBPs and used for detection of IgGs coming from numerous animal species. These results indicate that modified STIGA has the potential to be the start point for development of an easily applicable and inexpensive diagnostic test for total amount of IgGs in serum samples. With further development, appropriate optimization and design and validation of novel sensing elements able to bind IgGs from species not recognized by available IBP, STIGA assays could become applicable wide number of serum samples, coming from various species.

\section{Methods}

\section{Serum samples}

Serum samples were collected from 29 animal species (2 animals/species). Sera were acquired opportunistically from existing frozen collections in research labs at the University of Calgary and at the Calgary Zoo, under veterinary sciences animal care committee (VSACC) protocol AC16-0246 and Calgary Zoo Welfare, Ethics and Research Committee protocol 1,039,994, respectively.

\section{Strains, plasmids, and other materials}

Plasmids encoding for the biosensor used in this study were constructed according to the strategy used previously [25]. In short, 2 TreA fragment sequences, Tre $A^{N}$ (198 bp long) and $\operatorname{TreA}{ }^{C}$ (1368 bp long) were amplified by PCR from the coding sequence of the enzyme TreA. Each gene fragment was then fused at the $\mathrm{C}$-terminal with the coding sequence of 1 of 3 immunoglobulin binding proteins: Protein G (pG) (PBD: 2J52_A), protein A (pA) (PDB: 1HZ5_A) or protein L (pL) (PDB: 1BDC_ A) (IDT, Kanata, Canada). All recombinant genes were cloned in pETDuet expression vector (Novagen, Canada) using NcoI and AvrII restriction sites. Purified human 
IgG $(10 \mathrm{mg} / \mathrm{ml})$ used for standard curves was purchased from Sigma-Aldrich (Oakville, Canada).

\section{Protein purification and lyophilisation}

All recombinant proteins were expressed in E. coli expression strain BL-21 $\Delta$ TreA and purified on Ni-NTA resin (Thermo Fisher Scientific, Ottawa, Canada), as described [25]. In short, the protein expression was induced with $0.5 \mathrm{mM}$ of IPTG (isopropyl- $\beta$-D-1-thiogalactopyranoside) (UBP Bio, Aurora, $\mathrm{CO}$ ) for $3 \mathrm{~h}$ at $37^{\circ} \mathrm{C}$. Bacterial pellets expressing recombinant proteins were re-suspended in $6 \mathrm{M}$ guanidinium buffer, lysed by sonication and loaded on equilibrated Ni-NTA resin. Proteins were refolded on resin during washing steps containing gradually decreasing guanidinium- $\mathrm{HCl}$ (Sigma-Aldrich, Oakville, Canada) concentrations and eluted in an elution buffer containing $500 \mathrm{mM}$ of imidazole (Sigma-Aldrich, Oakville, Canada). Finally, samples were dialyzed against $1 \mathrm{~L}$ of sodium maleate buffer (Sigma-Aldrich, Oakville, Canada) (50 mM, pH 6) with Snakeskin (Fisher Thermo Fisher Scientific, Ottawa, Canada) for $24 \mathrm{~h}$ at $25^{\circ} \mathrm{C}$ and protein concentration determined by Qubit assay (Thermo Fisher Scientific, Ottawa, Canada).

\section{Split TreA detection assay for IgGs - modified STIGA} assay

Sera from every animal species used in the study was examined with 6 versions of this detection assay $\left(\right.$ TreA $^{\mathrm{C}}$
(C) and $\operatorname{Tre}^{\mathrm{N}}(\mathrm{N})$ fragments carrying different sensors): 1) N-pA + C-pA (AA assay); 2) N-pL + C-pL (LL assay); 3) N-pG + C-pG (GG assay); 4) N-pA + C-pL (AL assay); 5) N-pG + C-pA (GA assay); 6) N-pL + C-pG (LG assay) (Fig. 1).

Modified STIGA assay was performed with $10 \mu \mathrm{g}$ of C fragments and $2.85 \mu \mathrm{g}$ of $\mathrm{N}$ fragments ( 1 to $1 \mathrm{M}$ ratio) in sodium maleate buffer with $250 \mathrm{mM}$ of trehalose (Sigma-Aldrich, Oakville, Canada). Sera were diluted 1 in 100 in sodium maleate buffer $(50 \mathrm{mM}, \mathrm{pH} 6)$. The dilution factor (DF) was established experimentally (Additional file 1: Figure S1). The glucose concentration was measured with a colorimetric enzymatic assay based on glucose oxidase $(2.6 \mathrm{U} / \mathrm{mL}$; Sigma-Aldrich, Oakville, Canada), horseradish peroxidase $(0.2 \mathrm{U} / \mathrm{mL}$; Sigma), and O-dianisidine (0.5 mM; Sigma-Aldrich, Oakville, Canada) in sodium maleate buffer $(50 \mathrm{mM}, \mathrm{pH} 6)$. The final volume of each reaction was $150 \mu \mathrm{l}$. All the assays were performed in 96-well plate. Split TreA detection assay reagents were added to the plate; next sera samples were diluted into the reaction. Glucose detecting reagents were added at the end. The reaction was incubated for $90 \mathrm{~min}$ at $25^{\circ} \mathrm{C}$. Absorbance (OD) was measured after $90 \mathrm{~min}$ in EnSpire multimode plate reader at $450 \mathrm{~nm}$ (EnSpire, PerkinElmer, Waltham, MA) [24, 25].

\section{Data analyses}

Background signals caused by glucose in the sera were measured for each serum sample and subtracted from

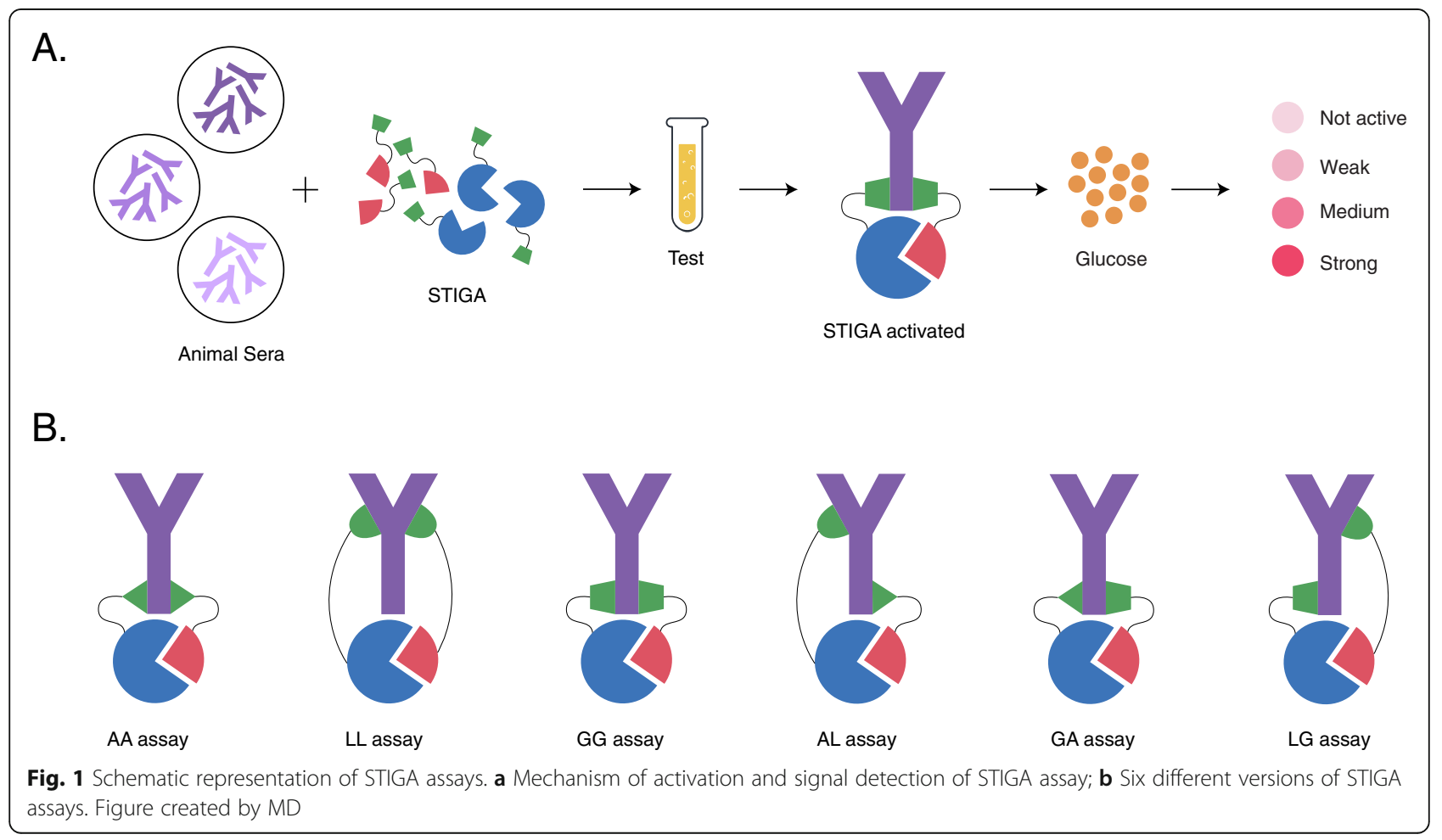


Table 4 Signal categories based on the intensity of different split TreA detection assay versions. Four different categories of signal were based on percentages of the signal obtained with human $\lg G$

\begin{tabular}{|c|c|}
\hline Signal & Percentage $^{a}$ \\
\hline Non Active (0.0) & $<10 \%$ \\
\hline Weak (1.0) & $10-30 \%$ \\
\hline Weak to Medium (2.0) & $30-50 \%$ \\
\hline Medium to Strong (3.0) & $50-70 \%$ \\
\hline Strong (4.0) & $>70 \%$ \\
\hline
\end{tabular}

the signal (OD value). All signals (OD values) were converted into a percentage and compared to the signal given by the purified human IgGs used, which was set as maximum (100\%) according to the following formula $\mathrm{OD}_{\mathrm{F}}=\left(\left(\mathrm{OD}_{\mathrm{S}}-\mathrm{OD}_{\mathrm{B}}\right) / \mathrm{OD}_{\mathrm{C}}\right)^{*} 100\left(\mathrm{OD}_{\mathrm{S}}\right.$ : Optical density of the animal serum with the biosensor (Signal); $\mathbf{O D}_{\mathbf{B}}$ : Optical density of the animal serum only (Background); OD $_{\mathbf{C}}$ : Optical density of purified human antibodies with the biosensor (Positive control)). Signals were split in 4 different categories according to their percentages: Non Active (0), Weak (1), Weak to Medium (2), Medium to Strong (3), Strong (4) (Table 4). Signals coming from the samples belonging to the same species were averaged and presented as a single datum point.

Animals were grouped according to the order they belong to (Class Aves - Order: Passiformes and Order: Passeriformes (Birds); Class Mammalia: and Order: Diprotodontia (Marsupials), Artiodactyla (Even-toed ungulates), Proboscidea (Proboscideans), Carnivora (Carnivores), Perissodactyla (Odd-toed ungulates), Lagomorpha (Lagomorphs), Rodentia (Rodents) and Primates (Primates)) and signals intensities were examined for each order and each species separately.

\section{Supplementary information}

Supplementary information accompanies this paper at https://doi.org/10. 1186/s12917-019-2126-z.

Additional file 1: Figure S1. Effect of human lgG concentration $(A ; n=$ 3) and serum dilution factor (DF) (B) (DF of $25 ; n=3) C(D F$ of $100 ; n=3$ ); D) (DF of $500 ; n=3$ ) on STIGA performance in sera samples of three animal species. Trehalase activity and the resulting glucose concentration were measured by GOx-HRP assay after 90 min of incubation at $25^{\circ} \mathrm{C}$.

\section{Abbreviations}

bIBP: Bacterial immunoglobulin binding proteins; ELISA: Enzyme-linked immunosorbent assay; IgG: Immunoglobulins G; OD: Optical density; pA: Protein A; pG: Protein G; pL: Protein L; RID: Radial immunodiffusion; STIGA: Split Trehalase lgG quantification assay

\section{Acknowledgments}

The authors would like to thank the Calgary Zoo staff for their involvement in collecting and storing blood samples from a variety of their Zoo animals over the years and Dr. John Kastelic for editing the manuscript.

\section{Authors' contributions}

$\mathrm{MD}$ and SO performed the enzymatic assays. MD and JDB analysed the obtained data and wrote the manuscript. JDB designed and coordinated the study. All authors read and approved the final manuscript.

\section{Funding}

This study was supported by a Discovery Grant to JDB from the Natural Sciences and Engineering Research Council of Canada (NSERC). NSERC played no role in the design of the study, nor in the collection, analysis, and interpretation of data nor in writing of the manuscript.

\section{Availability of data and materials}

The datasets analysed during the current study are available from the corresponding author on reasonable request.

Ethics approval and consent to participate

The study was approved by both the Veterinary Sciences Animal Care Committee (protocol AC16-0246) and Calgary Zoo Welfare, Ethics and Research Committee (protocol 1039994), implying consent to use previously taken serum samples from animals at UofC animal resource centres or the Calgary Zoo, respectively.

\section{Consent for publication}

Not applicable.

\section{Competing interests}

The authors declare that they have no competing interests.

Received: 29 November 2018 Accepted: 1 October 2019

Published online: 28 October 2019

References

1. Hill PB, Moriello KA, DeBoer DJ. Concentrations of total serum IgE, IgA, and IgG in atopic and parasitized dogs. Vet Immunol Immunopathol. 1995;44(2): 105-13 Epub 1995/01/01. PubMed PMID: 7747394.

2. Gatei MH, Lavin MF, Daniel RC. Serum immunoglobulin concentrations in cattle naturally infected with bovine leukemia virus. Zentralbl Veterinarmed B. 1990:37(8):575-80 Epub 1990/10/01. PubMed PMID: 2120873.

3. Nemeth NM, Oesterle PT, Bowen RA. Passive immunity to West Nile virus provides limited protection in a common passerine species. Am J Trop Med Hyg. 2008;79(2):283-90 Epub 2008/08/12. PubMed PMID: 18689637.

4. Kramsky JA, Manning EJ, Collins MT. Protein G binding to enriched serum immunoglobulin from nondomestic hoofstock species. J Vet Diagn Investig. 2003;15(3):253-61. https://doi.org/10.1177/104063870301500306 Epub 2003/ 05/09. PubMed PMID: 12735347.

5. Stobel K, Schonberg A, Staak C. A new non-species dependent ELISA for detection of antibodies to Borrelia burgdorferi s. I. in zoo animals. Int J Med Microbiol. 2002;291(Suppl 33):88-99 Epub 2002/07/27. PubMed PMID: 12141767

6. Yolken RH, Leister FJ. Staphylococcal protein A-enzyme immunoglobulin conjugates: versatile tools for enzyme immunoassays. J Immunol Methods. 1981;43(2):209-18 Epub 1981/01/01. PubMed PMID: 6267138.

7. Choe W, Durgannavar TA, Chung SJ. Fc-binding ligands of immunoglobulin G: an overview of high affinity proteins and peptides. Materials (Basel). 2016; 9(12). https://doi.org/10.3390/ma9120994 Epub 2017/08/05. PubMed PMID: 28774114; PubMed Central PMCID: PMCPMC5456964.

8. Roland Kontermann SD. Analysis and purification of antibody fragments using protein A, protein $\mathrm{G}$, and protein L. In: Roland Kontermann SD, editor. Antibody engineering. Berlin: Springer; 2010.

9. Forsgren A, Sjoquist J. Protein A from staphylococcus aureus. VII. Physicochemical and immunological characterization. Acta Pathol Microbiol Scand. 1969;75(3):466-80 Epub 1969/01/01. PubMed PMID: 4895644.

10. Forsgren A, Sjoquist J. "Protein A" from S. aureus. I. Pseudo-immune reaction with human gamma-globulin. J Immunol. 1966:97(6):822-7 Epub 1966/12 01. PubMed PMID: 4163007. 
11. Deisenhofer J. Crystallographic refinement and atomic models of a human Fc fragment and its complex with fragment B of protein A from staphylococcus aureus at 2.9- and 2.8-A resolution. Biochemistry. 1981;20(9): 2361-70 Epub 1981/04/28. PubMed PMID: 7236608.

12. Richman DD, Cleveland PH, Oxman MN, Johnson KM. The binding of staphylococcal protein A by the sera of different animal species. J Immunol. 1982;128(5):2300-5 Epub 1982/05/01. PubMed PMID: 7061862.

13. Bjorck L, Kronvall G. Purification and some properties of streptococcal protein G, a novel IgG-binding reagent. J Immunol. 1984;133(2):969-74 Epub 1984/08/01. PubMed PMID: 6234364.

14. Kato K, Lian LY, Barsukov IL, Derrick JP, Kim H, Tanaka R, et al. Model for the complex between protein $\mathrm{G}$ and an antibody Fc fragment in solution. Structure. 1995;3(1):79-85 Epub 1995/01/15. PubMed PMID: 7743134.

15. Akerstrom B, Brodin T, Reis K, Bjorck L. Protein G: a powerful tool for binding and detection of monoclonal and polyclonal antibodies. J Immunol. 1985;135(4):2589-92 Epub 1985/10/01. PubMed PMID: 4031496.

16. Bjorck $L$, Protein $L$. A novel bacterial cell wall protein with affinity for lg $L$ chains. J Immunol. 1988;140(4):1194-7 Epub 1988/02/15. PubMed PMID: 3125250.

17. De Chateau M, Nilson BH, Erntell M, Myhre E, Magnusson CG, Akerstrom B, et al. On the interaction between protein $L$ and immunoglobulins of various mammalian species. Scand J Immunol. 1993;37(4):399-405 Epub 1993/04/01. PubMed PMID: 8469922.

18. Graille M, Stura EA, Housden NG, Beckingham JA, Bottomley SP, Beale D, et al. Complex between peptostreptococcus magnus protein $\mathrm{L}$ and a human antibody reveals structural convergence in the interaction modes of Fab binding proteins. Structure. 2001;9(8):679-87 Epub 2001/10/06. PubMed PMID: 11587642

19. Eliasson M, Andersson R, Olsson A, Wigzell H, Uhlen M. Differential lgGbinding characteristics of staphylococcal protein $A$, streptococcal protein $G$, and a chimeric protein AG. J Immunol. 1989;142(2):575-81 Epub 1989/01/ 15. PubMed PMID: 2521350.

20. Nielsen K, Smith P, Yu W, Nicoletti P, Elzer P, Vigliocco A, et al. Enzyme immunoassay for the diagnosis of brucellosis: chimeric protein A-protein $G$ as a common enzyme labeled detection reagent for sera for different animal species. Vet Microbiol. 2004;101(2):123-9. https://doi.org/10.1016/j. vetmic.2004.02.014 Epub 2004/06/03. PubMed PMID: 15172695.

21. Kihlberg BM, Sjobring U, Kastern W, Bjorck L. Protein LG: a hybrid molecule with unique immunoglobulin binding properties. J Biol Chem. 1992;267(35): 25583-8 Epub 1992/12/15. PubMed PMID: 1460053.

22. Kihlberg BM, Sjoholm AG, Bjorck L, Sjobring U. Characterization of the binding properties of protein $L G$, an immunoglobulin-binding hybrid protein. Eur J Biochem. 1996;240(3):556-63 Epub 1996/09/15. PubMed PMID: 8856054.

23. Svensson $H G$, Hoogenboom HR, Sjobring U. Protein $L A$, a novel hybrid protein with unique single-chain Fv antibody-and Fab-binding properties. Eur J Biochem. 1998;258(2):890-6 Epub 1999/01/05. PubMed PMID: 9874260.

24. Drikic M, Windeyer C, Olsen S, Fu Y, Doepel L, De Buck J. Determining the IgG concentrations in bovine colostrum and calf sera with a novel enzymatic assay. J Anim Sci Biotechnol. 2018;9:69. https://doi.org/10.1186/ s40104-018-0287-4 Epub 2018/09/15. PubMed PMID: 30214721; PubMed Central PMCID: PMCPMC6131873.

25. Drikic M, De Buck J. Split trehalase as a versatile reporter for a wide range of biological analytes. Biotechnol Bioeng. 2018;115(5):1128-36. https://doi.org/ 10.1002/bit.26556 Epub 2018/02/08. PubMed PMID: 29411859

26. Gibson RP, Gloster TM, Roberts S, Warren RA, Storch de Gracia I, Garcia A, et al. Molecular basis for trehalase inhibition revealed by the structure of trehalase in complex with potent inhibitors. Angew Chem Int Ed Engl. 2007; 46(22):4115-9. https://doi.org/10.1002/anie.200604825 Epub 2007/04/25. PubMed PMID: 17455176.

27. Pruvot M, Forde TL, Steele J, Kutz SJ, De Buck J, van der Meer F, et al. The modification and evaluation of an ELISA test for the surveillance of Mycobacterium avium subsp. paratuberculosis infection in wild ruminants. BMC Vet Res. 2013;9:5. https://doi.org/10.1186/1746-6148-9-5 Epub 2013/01/ 11. PubMed PMID: 23302439; PubMed Central PMCID: PMCPMC3545983.

\section{Publisher's Note}

Springer Nature remains neutral with regard to jurisdictional claims in published maps and institutional affiliations.

Ready to submit your research? Choose BMC and benefit from:

- fast, convenient online submission

- thorough peer review by experienced researchers in your field

- rapid publication on acceptance

- support for research data, including large and complex data types

- gold Open Access which fosters wider collaboration and increased citations

- maximum visibility for your research: over $100 \mathrm{M}$ website views per year

At BMC, research is always in progress.

Learn more biomedcentral.com/submissions 